\title{
Pengaruh Variasi pH Medium terhadap Perolehan Biomassa Sel dan Laju Konsumsi Substrat Amonium pada Kultur Suspensi Sel Wortel (Daucus carota L.)
}

\author{
Keryanti ${ }^{1 *}$, Ahmad Faizal ${ }^{2}$, Sri Harjati Suhardi ${ }^{3}$ \\ ${ }^{1}$ Jurusan Teknik Kimia, Politeknik Negeri Bandung - Jl. Gegerkalong Hilir, Ds. Ciwaruga, Bandung 40012 \\ 2, 3 Sekolah Ilmu dan Teknologi Hayati, Institut Teknologi Bandung, - Jl. Ganesa No.10, Bandung 40132 \\ *e-mail corresponding author : keryanti@polban.ac.id.
}

\begin{abstract}
ABSTRAK
Pada penelitian ini, sistem kultur suspensi sel wortel (Daucus carota L.) digunakan sebagai model untuk mengetahui pengaruh variasi $\mathrm{pH}$ terhadap pertumbuhan biomassa sel serta laju konsumsi substrat amonium dalam medium. Kalus ditumbuhkan selama 24 hari dalam sistem batch pada medium cair MS (Murashige dan Skoog) dengan penambahan 4,5 x 10-6 M kinetin dan 4,5 × 10-6 M 2,4-D serta kondisi $\mathrm{pH}$ awal medium berbeda yaitu $\mathrm{pH} 4,5 ; 5,8$ dan 7,5. Perubahan $\mathrm{pH}$ medium diamati setiap 3 hari sekali disertai dengan pengukuran berat biomassa sel dan kandungan amonium dalam medium. Hasil pengamatan menunjukkan bahwa laju pertumbuhan spesifik biomassa sel paling tinggi terjadi pada kultur dengan kondisi $\mathrm{pH}$ awal medium 4,5 yaitu 0,08 hari $^{-1}$ sedangkan paling rendah pada kondisi $\mathrm{pH}$ awal medium 5,8 (kontrol) yaitu 0,02 hari $^{-1}$. Variasi $\mathrm{pH}$ awal medium menyebabkan perubahan dan fluktuasi nilai $\mathrm{pH}$ dalam medium sehingga mempengaruhi tingkat penyerapan substrat amonium dalam medium. Laju konsumsi amonium tertinggi terjadi pada kultur perlakuan $\mathrm{pH}$ awal medium 4,5 yaitu sebesar $0,088 \mathrm{mM} /$ hari. Penggunaan amonium untuk pertumbuhan biomassa juga paling efektif pada kultur dengan kondisi $\mathrm{pH}$ awal medium 4,5 dengan nilai perolehan biomassa per substrat amonium mencapai $0,875 \mathrm{~g} \mathrm{sel} / \mathrm{mM}$ amonium. Penelitian ini dapat memberikan gambaran mekanisme dan efisiensi penyerapan media pada medium pertumbuhan sehingga dapat diterapkan untuk pengendalian sistem produksi terutama sistem bioreaktor.
\end{abstract}

Kata kunci : amonium; batch; Daucus carota L.; pH; pertumbuhan sel

\begin{abstract}
In this experiment, a carrot (Daucus carota L.) cell suspension system was used as a model to determine the effect of $p H$ variations on cell biomass growth and the rate of consumption of ammonium substrates in the medium. Callus was grown for 24 days in a batch system on MS liquid medium (Murashige and Skoog) with the addition of 4.5 × 10-6 M kinetin and 4.5 $\times 10-6 M$ 2,4-D and the initial $p H$ of the medium was different, namely $p H 4,5 ; 5.8$; and 7.5. Changes in the medium's $p H$ were observed every three days, accompanied by cell biomass weight measurements and ammonium content in the medium. The observations showed that the bighest specific cell growth rate occurred in cultures with medium $p H$ initial conditions of 4.5, 0.08 days-1, while the lowest at medium $p H$ conditions of 5.8 (control), 0.02 days-1. Variations in the initial $p H$ of the medium cause changes and fluctuations in the medium's $p H$ value so that it affects the rate of absorption of ammonium substrates in the medium. The bighest ammonium consumption rate occurred in the culture medium initial $\mathrm{pH}$ treatment equal to $0.088 \mathrm{mM} /$ day. The use of ammonium for biomass growth is most effective in cultures with an initial $p H$ medium condition of 4.5 with the acquisition value of biomass per ammonium substrate, reaching $0.875 \mathrm{~g}$ cells/ $\mathrm{mM}$ ammonium. This research can provide an overview of the mechanism and efficiency of media absorption in the growth medium to be applied to control production systems, especially in bioreactor systems.
\end{abstract}

Keywords : ammonium; batch; cell growth; Daucus carota L.; pH

Cara mengutip: Keryanti, Faizal, A., \& Suhardi, S. H. (2020). Pengaruh Variasi pH Medium terhadap Perolehan Biomassa Sel dan Laju Konsumsi Substrat Amonium pada Kultur Suspensi Sel Wortel (Daucus carota L.). Reka Buana : Jurnal Ilmiah Teknik Sipil dan Teknik Kimia, 5(2), 125-134. http://dx.doi.org/10.33366/rekabuana.v5i2.1764 


\section{PENDAHULUAN}

Pertumbuhan sel tanaman dalam kultur diketahui dipengaruhi oleh berbagai faktor salah satunya yaitu $\mathrm{pH}$ medium. Selama perumbuhan sel dalam kultur, $\mathrm{pH}$ medium pertumbuhan mengalami fluktuasi sehingga sel tidak berada pada $\mathrm{pH}$ konstan kecuali ketika pertumbuhan berada pada fase stasioner [1]. Fluktuasi pH medium kultur ini dapat disebabkan oleh aktivitas metabolik sel baik oleh pompa ion hidrogen ke dalam medium kultur maupun akibat metabolisme senyawa buffer (penyangga) dalam medium kultur [2].

Perubahan kondisi pH telah dilaporkan dapat menginisiasi dan mengendalikan beberapa proses metabolik penting dalam sel tumbuhan [3]. Penelitian lain pada sel Ipomoea yang ditumbuhkan dalam kultur batch pada $\mathrm{pH}$ terkendali menunjukkan terjadinya penurunan laju penyerapan amonium serta peningkatan laju penyerapan nitrat pada $\mathrm{pH}$ yang semakin menurun [4].

Steiner dan Dougall [5] telah mengamati pengaruh $\mathrm{pH}$ medium terhadap laju pertumbuhan dan perolehan senyawa antosianin pada kultur suspensi sel wortel (Daucus carota L.) dalam sistem semicontinuous culture (SCC). Dalam sistem SCC, ketika nilai karakteristik tertentu misalnya $\mathrm{pH}$ dan berat kering sel per $\mathrm{mL}$ menunjukkan nilai yang konstan pada waktu pengukuran berbeda, dapat dikatakan bahwa kultur dalam kondisi tunak (steady state). Dalam SCC, densitas kultur sel sebanding dengan konsentrasi amonium pada input medium dan digunakan seluruhnya oleh sel.

Pengaruh $\mathrm{pH}$ medium pertumbuhan dapat diamati pada kultur suspensi sel sebagai sistem model karena sel dapat ditumbuhkan pada lingkungan homogen tertentu seperti temperatur, cahaya, $\mathrm{pH}$ medium, nutrien, dan lain-lain [6] sehingga analisis hasil dan mekanisme regulasi menjadi lebih mudah. Proses metabolisme sel pada sistem kultur suspensi sel lebih tinggi daripada kultur kalus karena terjadi kontak langsung antara permukaan sel dengan nutrisi yang diberikan pada lingkungan yang homogen dan luas permukaan lebih besar [2].

Pada penelitian ini dimodelkan bagaimana laju penyerapan amonium pada kultur suspensi sel wortel dihubungkan dengan perolehan biomassa selnya. Percobaan dilakukan dalam sistem batch sehingga akan dilihat laju penyerapan amoniumnya setiap waktu tertentu dikaitkan dengan data profil $\mathrm{pH}$ medium dan berat kering sel. Penelitian ini diharapkan dapat menggambarkan bagaimana nutrisi diserap oleh sel tumbuhan serta efisiensinya sehingga dapat diterapkan untuk pengendalian sistem produksi terutama sistem bioreaktor.

\section{METODE PENELITIAN}

Penelitian dilakukan dalam beberapa tahapan meliputi (1) Penyiapan kultur kalus (2) Inokulasi dan perlakuan variasi $\mathrm{pH}$ awal pada kultur suspensi sel (3) Pengamatan pertumbuhan sel dan perubahan $\mathrm{pH}$ medium (4) Pengolahan data perolehan biomassa sel serta pemodelan.

\subsection{Penyiapan Kultur Kalus}

Penelitian ini menggunakan kalus wortel yang diperoleh dari hasil induksi eksplan berupa potongan empulur wortel pada medium MS [7] padat dengan penambahan kinetin dan 2,4-Dichlorophenoxy acetic acid (2,4-D) dengan konsentrasi masing-masing sebesar $4 \times 10^{-6}$ M. Kalus ditumbuhkan selama 40 hari pada kondisi temperatur $25^{\circ} \mathrm{C}$ dan pencahayaan 24 jam. 


\subsection{Kultur Suspensi Sel dan Perlakuan}

Kalus terbaik berwarna hijau dan telah meremah yang diperoleh dari kultur kalus diinokulasikan ke dalam medium cair MS yang ditambahkan kinetin dan 2,4-D dengan konsentrasi yang sama dengan medium induksi kalus. Perlakuan variasi $\mathrm{pH}$ awal $(4,5$; 5,8 dan 7,5) dilakukan dengan penambahan larutan stok $\mathrm{NaOH} / \mathrm{HCl}$ 0,2 $\mathrm{M}$ ke dalam medium kultur suspensi sel dan diukur menggunakan $\mathrm{pH}$ meter. $\mathrm{pH}$ 5,8 digunakan sebagai kontrol karena pada $\mathrm{pH}$ tersebut biasanya kultur suspensi dilakukan. Masingmasing botol perlakuan berisi 0,1 $\mathrm{g}$ sel wortel dalam $10 \mathrm{~mL}$ medium. Percobaan dilakukan selama 24 hari dan dialkukan pengamatan setiap 3 hari sekali.

\subsection{Kurva Pertumbuhan Sel}

Kurva pertumbuhan sel dibuat untuk melihat profil berat kering sel terhadap waktu (umur kultur). Berat kering sel didapatkan setelah sel melalui tahap pengeringan menggunakan oven hingga mencapai berat konstan. Pengambilan sampel untuk pengukuran berat kering dilakukan setiap 3 hari hingga umur 24 hari.

\subsection{Kurva Perubahan $\mathrm{pH}$ Medium}

Kurva perubahan $\mathrm{pH}$ medium dibuat untuk profil perubahan tingkat keasaman medium sepanjang waktu (umur kultur). Medium yang telah disimpan dalam tabung Falcon diukur $\mathrm{pH}$-nya menggunakan $\mathrm{pH}$ meter lalu dicatat nilainya untuk dianalisis. Medium tersebut lalu disimpan didalam freezer dengan suhu $-4^{\circ} \mathrm{C}$ untuk pengukuran kadar amonium.

\subsection{Kurva Kandungan Amonium}

Kurva kandungan amonium ditentukan dari hasil pengukuran kandungan amonium di dalam medium menggunakan metode Nessler. Sebanyak $25 \mathrm{~mL}$ sampel ditambahkan dengan 2 tetes reagen Seignette dan $0,5 \mathrm{~mL}$ reagen Nessler. Campuran kemudian diaduk dan didiamkan selama 10 menit. Absorbansi senyawa amonium pada medium kemudian diukur dengan spektofotometer pada panjang gelombang $425 \mathrm{~nm}$. Nilai absorbansi yang dihasilkan dimasukkan ke dalam persamaan kurva standar yang telah diperoleh sebelumnya untuk larutan standar amonia dari senyawa amonium klorida $\left(\mathrm{NH}_{4} \mathrm{Cl}\right)$.

\subsection{Perolehan Biomassa Sel terhadap}

\section{Konsumsi Amonium}

Perolehan biomassa (g sel/g amonium) dihitung menggunakan Persamaan 1 [8]:

$$
\mathrm{Y}_{\mathrm{XS}}=\frac{\left(\frac{\mathrm{dx}}{\mathrm{dt}}\right)}{\left(\frac{\mathrm{ds}}{\mathrm{dt}}\right)}=-\frac{\Delta \mathrm{X}}{\Delta \mathrm{S}}
$$

keterangan:

$\mathrm{dx} / \mathrm{dt}=$ Laju pertumbuhan biomassa sel $\mathrm{dS} / \mathrm{dt}=$ Laju konsumsi amonium

Hubungan antara laju pertumbuhan sel dan laju penyerapan amonium dimodelkan dengan software Barkeley Madonna. Algoritma yang dibangun untuk pemodelan menggunakan persamaan Monod [8] berikut:

$$
\mu=\frac{\mu_{\mathrm{m}} \mathrm{s}}{\mathrm{k}_{\mathrm{s}}+\mathrm{s}}
$$

keterangan:

$\mu=$ Laju pertumbuhan spesifik sel (hari ${ }^{-1}$ )

$\mu_{\mathrm{m}}=$ Laju pertumbuhan spesifik sel maksimum (hari ${ }^{-1}$ )

$\mathrm{k}_{\mathrm{s}}=$ Ketetapan kejenuhan substrat amonium $(\mathrm{mM})$

$\mathrm{S}=$ Konsentrasi amonium $(\mathrm{mM})$.

\section{HASIL DAN PEMBAHASAN}

Pertumbuhan kalus sel wortel pada proses inisiasi kalus mulai dapat diamati saat eksplan sudah berumur $7-10$ hari pengamatan. Hal ini terlihat dari mulai munculnya kalus berwarna hijau dari bagian 
eksplan empulur wortel yang sebelumnya dilukai. Kalus terus tumbuh danberkembang sampai seluruh bagian eksplan wortel yang semula berwarna orange menjadi kalus sepenuhnya. Gambar 1 menunjukkan kalus wortel yang terbentuk pada medium padat setelah usia 40 hari. Kalus yang dihasilkan berwarna hijau muda dan bertekstur remah.

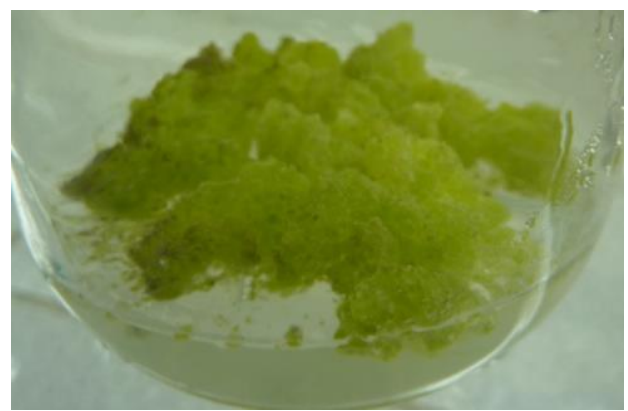

Gambar 1. Kultur kalus wortel pada media padat

Setelah inisiasi pembentukan kalus dalam medium padat, kalus disubkultur ke medium MS cair untuk membentuk sistem suspensi sel yang bertujuan untuk proses aklimatisasi sebelum perlakuan. Aklimatisasi dalam kultur suspensi ini dilakukan selama 5 hari. Selama aklimatisasi ini, sel wortel mengalami adaptasi. Dalam sistem kultur suspensi, sel wortel akan kontak langsung dengan medium sehingga pertumbuhan dan metabolismenya dapat dijadikan sebagai sistem model akibat perlakuan tertentu dalam hal ini variasi $\mathrm{pH}$ awal medium.

Selama aklimatisasi maupun perlakuan variasi $\mathrm{pH}$ awal medium, kultur sel suspensi diberikan agitasi atau pengocokan sebesar $120 \mathrm{rpm}$. Agitasi ini bertujuan untuk memisahkan kalus meremah membentuk selsel tunggal ataupun kelompok sel sehingga luas permukaan sel untuk kontak langsung dengan medium semakin besar [2]. Agitasi pada kultur suspensi sel dapat mempengaruhi ukuran agregat, viabilitas dan pertumbuhan sel. Selain itu agitasi juga dapat meningkatkan kandungan oksigen dalam kultur [9]. Kultur suspensi sel wortel selama perlakuan ditunjukkan pada Gambar 2.

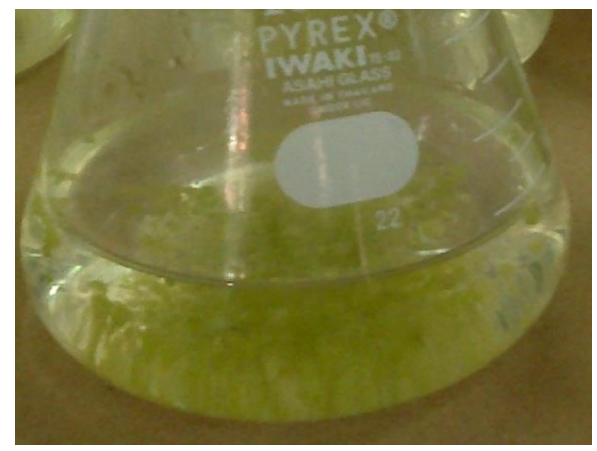

\section{Gambar 2. Kultur suspensi sel wortel}

Pertumbuhan biomassa yang diperoleh menggunakan data berat kering sel, ditunjukkan pada Gambar 3. Data berat kering sel lebih representatif digunakan daripada berat basah karena diasumsikan semua kandungan air dan senyawa terlarut lain di dalam sel telah menguap. Oleh karena itu, biomassa sel kering dianggap merupakan hasil konversi dan metabolisme dari penyerapan nutrisi dalam medium dan kondisi yang telah disediakan.

Pada kedua perlakuan $\mathrm{pH}$ awal medium yaitu 7,5 dan kontrol $(5,8)$ terjadi pertumbuhan fase lag (penyesuaian) sampai umur kultur 6 hari sedangkan perlakuan $\mathrm{pH}$ awal medium 4,5 mengalami fase lag sampai umur 9 hari. Pada kontrol, dari umur kultur 6 sampai 18 hari sel mengalami pertumbuhan fase logaritmik lalu turun hingga hari ke-24. Sedangkan sel pada kedua perlakuan masih mengalami fase logaritmik hingga hari ke-24. Penurunan pertumbuhan sel dari hari ke-18 sampai ke-24 pada kontrol dapat terjadi akibat akumulasi metabolit yang bersifat toksik bagi sel dan terjadinya lisis atau kematian sel [10]. 


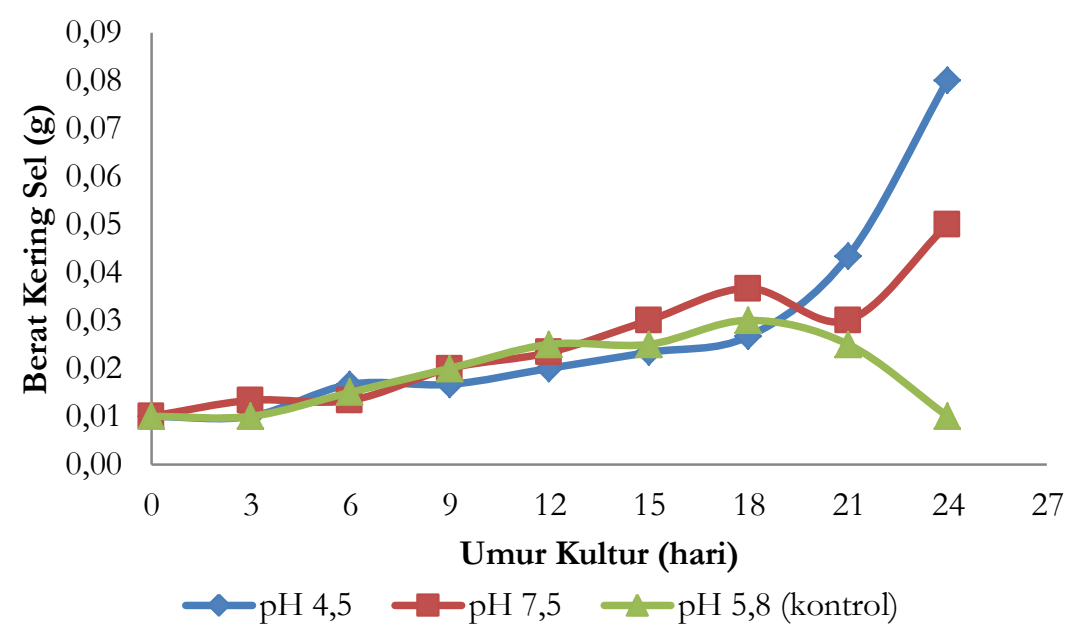

Gambar 3. Pertumbuhan berat kering sel wortel pada berbagai $\mathrm{pH}$ awal medium berbeda

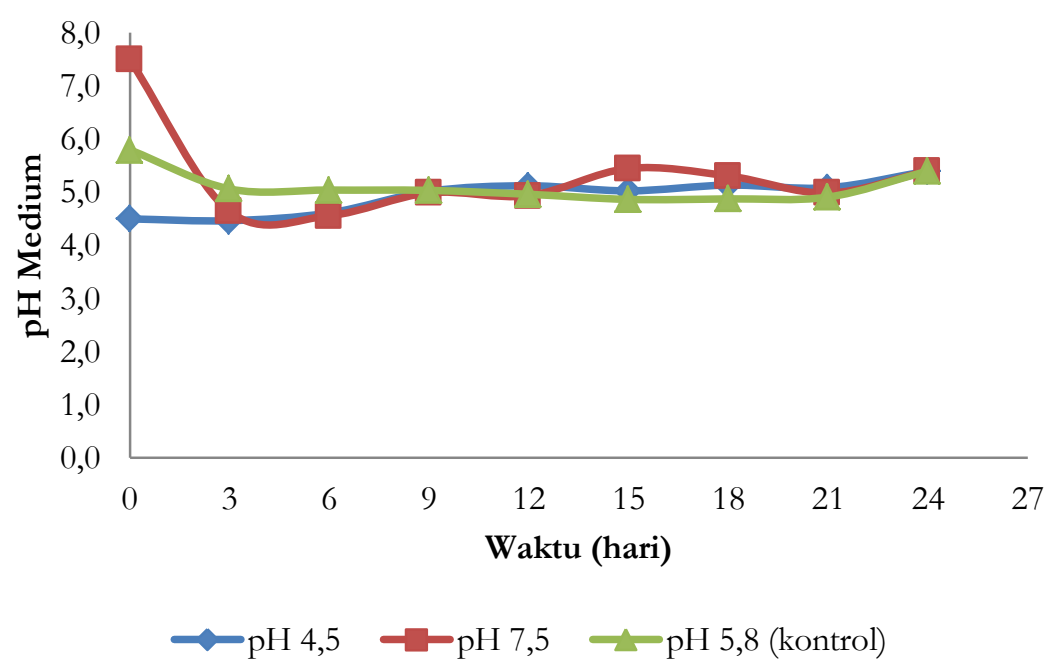

Gambar 4. Perubahan nilai $\mathrm{pH}$ medium kultur suspensi wortel dengan $\mathrm{pH}$ awal medium yang berbeda

Laju pertumbuhan spesifik dari masingmasing perlakuan kultur suspensi sel wortel dengan $\mathrm{pH}$ awal medium 4,5 dan 7,5 serta kontrol ditunjukkan pada Tabel 1.

Tabel 1. Laju pertumbuhan spesifik sel wortel pada berbagai $\mathrm{pH}$ awal medium berbeda

\begin{tabular}{ccc}
\hline $\begin{array}{c}\text { pH awal } \\
\text { Medium }\end{array}$ & $\begin{array}{c}\text { Laju Pertumbuhan } \\
\text { Spesifik, } \boldsymbol{\mu}\left(\text { hari- }^{-1}\right)\end{array}$ & $\begin{array}{c}\text { Laju Pertumbuhan } \\
\text { Spesifik maksimal, } \\
\boldsymbol{\mu}_{\mathrm{m}}\left(\text { hari }^{-1}\right)\end{array}$ \\
\hline 4,5 & 0,08 & 0,14 \\
7,5 & 0,06 & 0,09 \\
5,8 & 0,02 & 0,10 \\
\hline
\end{tabular}

Perbedaan laju pertumbuhan sel dalam kultur suspensi ini dapat merupakan dampak dari mekanisme sel untuk meregulasi $\mathrm{pH}$ medium serta ketersediaan substrat nutrien dalam medium.

Pada Gambar 4 ditunjukkan kurva perubahan nilai $\mathrm{pH}$ medium untuk perlakuan $\mathrm{pH}$ awal medium 4,5 dan 7,5 serta kontrol (pH awal 5,8). Secara keseluruhan, walaupun $\mathrm{pH}$ awal medium berbeda-beda, ketiga variasi menunjukkan kecenderungan menuju nilai $\mathrm{pH}$ yang sama yaitu menuju $\mathrm{pH} 4,5$ sampai 5 pada hari ke-6. Hal ini menunjukkan bahwa 
terjadinya asidifikasi di dalam medium akibat penggunaan senyawa ammonium.

Nilai $\mathrm{pH}$ medium pada variasi $\mathrm{pH}$ awal 4.5 dan 7.5 mencapai sekitar 5 pada hari ke-6, dan selanjutnya terus mengalami peningkatan $\mathrm{pH}$ hingga hari ke-15. Hal ini merupakan indikasi bahwa substrat yang digunakan adalah nitrat. Nilai $\mathrm{pH}$ medium kembali mengalami penurunan hingga hari ke-21 lalu naik kembali pada hari ke-24. Sedangkan $\mathrm{pH}$ untuk medium kontrol cenderung konstan di angka 4,9 - 5,0 sampai hari ke-21 kemudian mengalami penurunan pada hari ke-24.

Tabel 2. Tabel 2 Rata-rata $\mathrm{pH}$ medium saat pengamatan

\begin{tabular}{cc}
\hline $\begin{array}{c}\text { Variasi pH awal } \\
\text { medium }\end{array}$ & Rata-rata $\mathbf{p H}$ medium \\
\hline 5,8 & 5,1 \\
4,5 & 4,9 \\
7,5 & 5,3 \\
\hline
\end{tabular}

Nilai rata-rata $\mathrm{pH}$ medium untuk masing-masing variasi setiap waktunya ditampilkan dalam Tabel 2. Dapat dilihat bahwa secara keseluruhan, $\mathrm{pH}$ medium menuju ke arah nilai yang konstan di rentang 4,9 - 5,3. Hal ini menunjukkan bahwa di rentang $\mathrm{pH}$ itulah pertumbuhan sel wortel dalam kultur suspensi terjadi lebih optimal.

Amonium dalam medium digunakan sebagai salah satu sumber nitrogen untuk pertumbuhan sel dan produksi senyawa metabolit dalam kultur suspensi sel wortel. Sumber nitrogen dalam kultur suspensi sel wortel ini diberikan dalam bentuk senyawa amonium nitrat $\left(\mathrm{NH}_{4} \mathrm{NO}_{3}\right)$ yang merupakan salah satu komposisi dasar pada medium Murashige dan Skoog (MS).

Gambar 5 menunjukkan kurva kadar amonium (mM) yang tersisa pada medium untuk masing-masing variasi perlakuan. Secara umum, penurunan kadar amonium dalam medium paling tinggi terjadi pada saat sel mengalami fase logaritmik pertumbuhan. Hal ini menunjukkan bahwa konsumsi amonium sebanding dengan pertumbuhan biomassa sel.

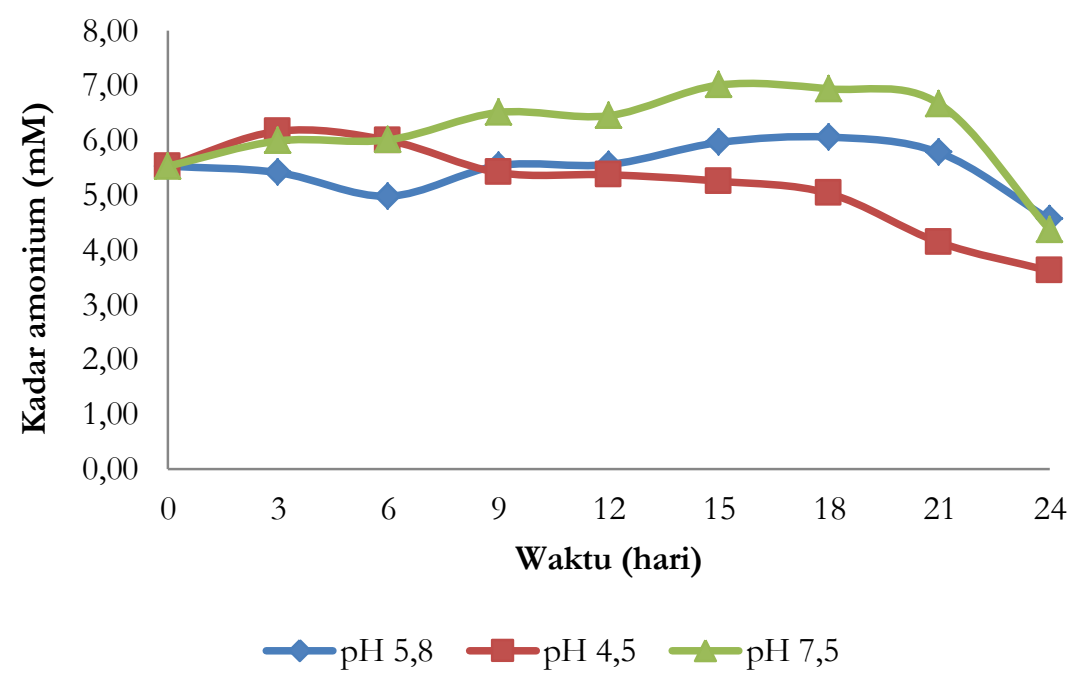

Gambar 5. Perubahan kadar amonium dalam medium kultur suspensi wortel dengan $\mathrm{pH}$ awal medium yang berbeda 
Pada Gambar 5 terlihat bahwa konsumsi amonium tertinggi terjadi pada kultur dengan perlakuan $\mathrm{pH}$ awal medium 4,5 yaitu sebesar $0,088 \mathrm{mM} /$ hari. Konsumsi amonium pada perlakuan $\mathrm{pH}$ awal 7,5 dan kontrol masing-masing adalah 0,0013 dan $0,0012 \mathrm{mM} /$ hari.

Berdasarkan hasil penelitian ini, dapat disimpulkan bahwa $\mathrm{pH}$ memengaruhi laju penyerapan amonium pada sel wortel. Laju penyerapan amonium terbesar terjadi pada sel yang ditumbuhkan pada medium perlakuan dengan $\mathrm{pH}$ awal 4,5. Hal ini sesuai dengan hasil penelitian dari Stainer dan Dougall [5] pada sistem semicontinous culture yang dibatasi amonium, sel wortel yang ditumbuhkan pada medium dengan $\mathrm{pH}$ 4,5 menunjukkan rata-rata laju penyerapan amoniumnya mencapai 25\% lebih tinggi dibandingkan sel yang ditumbuhkan pada medium dengan $\mathrm{pH}$ 5,5 dan 6,5. Pada penelitian ini, sistem yang digunakan adalah batch, sehingga $\mathrm{pH}$ tidak dapat dipertahankan sesuai perlakuan yang diinginkan. Akan tetapi perubahan nilai $\mathrm{pH}$ pada perlakuan $\mathrm{pH}$ awal 4,5 tidak terlalu signifikan dan menunjukkan nilai $\mathrm{pH}$ yang cenderung tetap rendah dibanding perlakuan lainnya.

Kadar amonium pada hari ke-24 pada perlakuan ini pun menunjukkan kadar yang paling rendah yaitu 3,62 mM. Laju penyerapan amonium yang berbeda ini dipengaruhi oleh ukuran agregasi sel selama masa pertumbuhan dalam kultur [5]. Perubahan $\mathrm{pH}$ menginduksi distribusi ukuran agregat sel yang berbeda sehingga menyebabkan laju penyerapan amonium yang berbeda pula. Korelasi ini dapat dijelaskan dengan konsep efek difusi yang dipengaruhi ukuran agregat sel yang merupakan respon dari perbedaan $\mathrm{pH}$ medium. Pada penelitian Stainer dan Dougall tersebut diamati bahwa pada medium dengan $\mathrm{pH} 4,5$ ukuran agregat selnya kecil-kecil sehingga luas permukaan selnya lebih besar dibandingkan perlakuan lain. Luas area yang semakin besar menyebabkan kontak sel dengan medium semakin besar sehingga laju penyerapan amonium lebih tinggi.

Fenomena tersebut juga teramati pada penelitian ini. Walaupun tidak dilakukan pengamatan ukuran agregat sel, tingkat pertumbuhan sel tertinggi terjadi pada perlakuan $\mathrm{pH}$ awal medium 4,5 yaitu sebesar 0,08 hari-1. Hal ini sebanding dengan laju penyerapan amoniumnya yang juga semakin tinggi dibandingkan perlakuan $\mathrm{pH}$ awal medium 7,5 dan kontrol.

Dalam kultur suspensi sel, pemisahan dan agregasi sel juga dipengaruhi oleh shear forces yang dihasilkan dari proses agitasi. Shear stress ini secara langsung sebanding dengan laju rotasi pada kultur [5]. Kombinasi laju rotasi serta kekuatan dinding sel inilah yang menentukan distribusi ukuran agregat sel dalam kultur.

Pada Gambar 6 ditunjukkan grafik perolehan biomassa untuk masing-masing perlakuan. Nilai perolehan biomassa diperoleh menggunakan persamaan 1 atau dapat dihitung dari selisih berat biomassa sel dibagi selisih kadar amonium dalam medium. Dalam hal ini, ion amonium dalam medium kultur suspensi diasumsi dimanfaatkan oleh sel hanya untuk pertumbuhan.

Perolehan biomassa per substrat amonium tertinggi terjadi pada perlakuan $\mathrm{pH}$ awal medium 4,5 yaitu $0,875 \mathrm{~g}$ sel $/ \mathrm{mM}$ amonium. Hal ini menunjukkan bahwa kondisi inilah yang paling efektif dalam pengunaan amonium untuk pertumbuhan sel dibandingkan pada kondisi $\mathrm{pH}$ lainnya. 


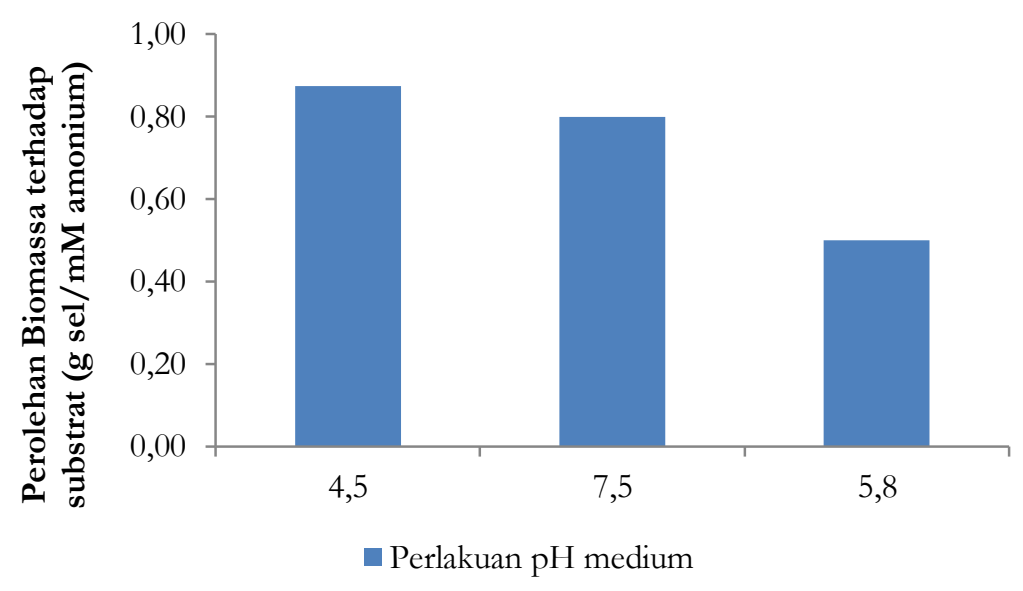

Gambar 6. Perolehan biomassa sel terhadap substrat amonium

Model matematika sederhana disusun untuk mencari ketetapan kejenuhan substrat amonium berdasarkan beberapa asumsi proses sebagai berikut:

1. Pengaruh nutrisi yang akan dimodelkan hanya untuk satu variabel berupa sumber nitrogen yaitu ion amonium.

2. Substrat amonium diasumsi digunakan untuk pertumbuhan biomassa sel.

Berdasarkan asumsi tersebut maka laju pertumbuhan sel terhadap substrat amonium didekatkan dengan persamaan Monod [8]. Nilai laju pertumbuhan spesifik dan laju pertumbuhan spesifik maksimum sel pada kultur perlakuan $\mathrm{pH}$ awal medium 4,5 masing-masing sebesar 0,08 hari $^{-1}$ dan 0,14 hari ${ }^{-1}$. Konsentrasi amonium dalam medium MS adalah sebesar 5,53 mM. Dari perhitungan menggunakan persamaan Monod diperoleh ketetapan kejenuhan substrat amonium sebesar 4,15 $\mathrm{mM}$. Ini menunjukan bahwa pada konsentrasi 4,15 $\mathrm{mM}$ laju pertumbuhan spesifiknya sudah mencapai setengah dari laju pertumbuhan spesifik maksimum.
Persamaan yang didapat dalam permodelan laju penyerapan amonium dan pertumbuhan biomassa sel adalah:

$$
\mu=\frac{0,14 \times \mathrm{S}}{4,15+\mathrm{S}}
$$

Kurva yang dihasilkan dari pemodelan tersebut menggunakan software Barkeley Madonna terlihat pada Gambar 7.

Nilai hipotetikal data berat kering dan kadar amonium sisa dalam medium berbeda jika dibandingkan dengan nilai aktual yang diperoleh dari hasil pengamatan. Dari pemodelan diprediksi bahwa pada hari ke 24 pengamatan berat kering sel sebesar 0,067 $\mathrm{g}$ sedangkan kadar amonium medium adalah 3,6 mM. Data aktual pengamatan diperoleh berat kering sel mencapai $0,08 \mathrm{~g}$ sedangkan kadar amonium adalah 3,62 mM. Perbedaan nilai tersebut dapat terjadi akibat kurang sesuainya penggunaan persamaan Monod. Selain itu pertumbuhan biomassa juga dapat dipengaruhi oleh substrat lain di medium seperti sukrosa dan sumber senyawa fosfat. 


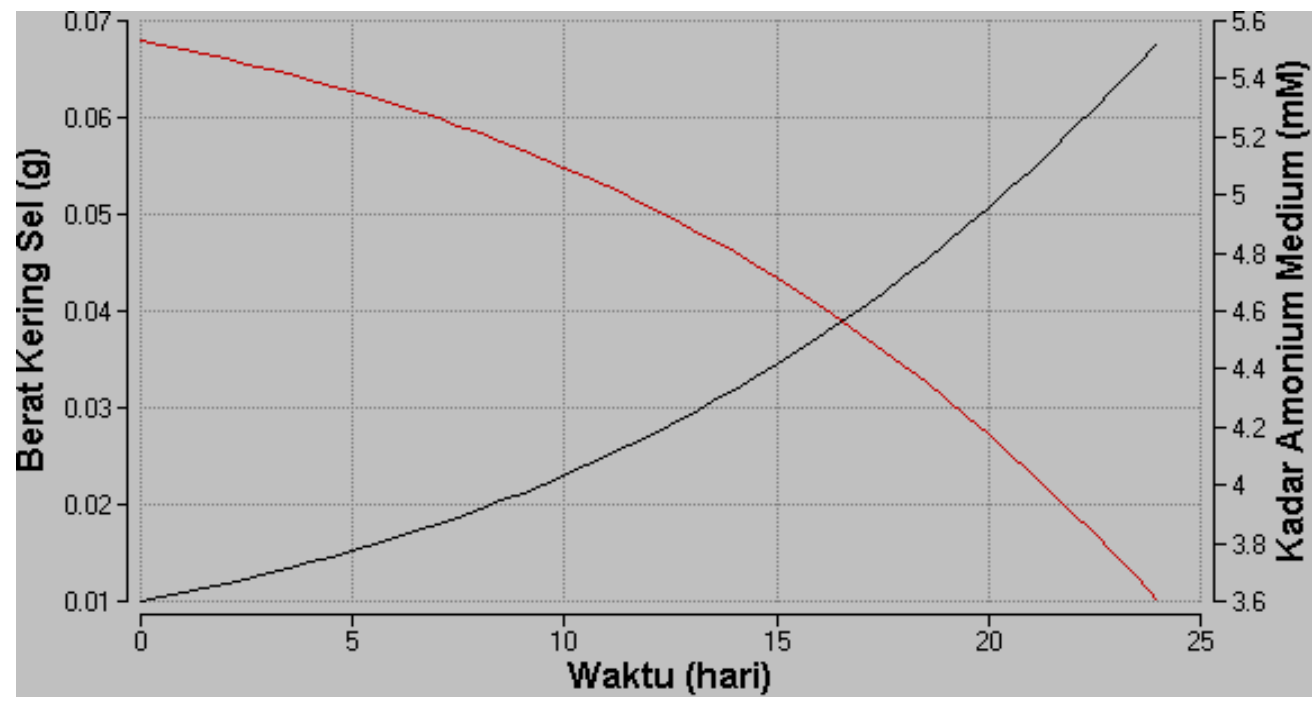

— kadar amonium medium $(\mathrm{mM})$

— : berat kering sel $(\mathrm{g})$

\section{Gambar 7. Hubungan laju pertumbuhan biomassa dengan konsumsi amonium}

\section{KESIMPULAN}

Variasi $\mathrm{pH}$ awal medium menyebabkan perubahan nilai $\mathrm{pH}$ sehingga mempengaruhi tingkat penyerapan substrat amonium dalam medium. Penyerapan amonium tertinggi terjadi saat pertumbuhan sel mengalami fasa eksponensial untuk masing-masing perlakuan. Laju pertumbuhan spesifik biomassa sel tertinggi terjadi pada perlakuan $\mathrm{pH}$ awal medium 4,5. Perolehan biomassa sel terhadap substrat amonium tertinggi terjadi pada perlakuan $\mathrm{pH}$ awal medium 7,5. Hal ini menunjukkan bahwa kultur perlakuan $\mathrm{pH}$ awal 7,5 lebih efektif menggunakan amonium untuk pertumbuhan biomassa dibanding dua perlakuan lainnya.

\section{DAFTAR PUSTAKA}

[1] D. K. Dougall, "Nutrition and Metabolism," in Staba ET (Ed) Plant Tissue Culture as a Source of Biochemicals, Boca Raton, Florida: CRC Press, 1980, pp. 21-58.

[2] E. F. George, M. A. Hall, and G.-J. De Klerk, "The Components of Plant
Tissue Culture Media II: Organic Additions, Osmotic and pH Effects, and Support Systems," in Plant Propagation by Tissue Culture: Volume 1. The Background, E. F. George, M. A. Hall, and G.-J. De Klerk, Eds. Dordrecht: Springer Netherlands, 2008, pp. 115-173.

[3] W. F. Boron, "Regulation of intracellular pH," Am. J. Physiol. - Adv. Physiol. Educ., vol. 28, no. 4, pp. 160-179, 2004.

[4] C. M. Ramage and R. R. Williams, "Mineral Nutrition and Plant Morphogenesis," Vitr. Cell. Dev. Biol. Plant, vol. 38, no. 2, pp. 116-124, Feb. 2002.

[5] H. - Y Steiner and D. K. Dougall, "Ammonium uptake in carrot cell structures is influenced by $\mathrm{pH}$ dependent cell aggregation," Physiol. Plant., vol. 95, no. 3, pp. 415-422, 1995.

[6] S. Afzal, M. Zia, and M. F. Chaudhary, "Uptake of nitrate and ammonium ion by cell suspension cultures of Vigna radiata," Pakistan J. Bot., vol. 38, no. 1, 
pp. 85-88, 2006.

[7] T. Murashige and F. Skoog, "Murashige1962Revised.Pdf," Physiol. Plant., vol. 15, pp. 474-497, 1962.

[8] M. L. Shuler and F. Kargi, Bioprocess Engineering Basic Concepts, Second Edi. New Jersey, USA: Prentice Hall PTR, 2002.

[9] X. Liu et al., "Effects of calcium concentration on aggregates formation, growth and metabolism of HEK293 cells in suspension culture," Chin. J. Biotechnol., vol. 16, no. 6, pp. 615-618, 2006.

[10] Z. Zakiah, E. Marwani, and A. H. Siregar, "Peningkatan Produksi Azadirahtin dalam Kultur Suspensi Sel Azadirachta indica A.Juss melalui Penambahan Skualen," J. Mat. dan Sains; Vol 8 No 4, 2009. 